\title{
PERANCANGAN SISTEM INFORMASI PELAYANAN PADA POSYANDU SERUNI KELURAHAN PANGKALANJATI BARU BERBASIS JAVA
}

\author{
Muhamad Kurnia Rangga \\ Universitas Indraprasta PGRI \\ Jalan Raya Tenganh, Gedong, Pasar Rebo, Jakarta Timur, Daerah Khusus Ibukota Jakarta 13760 \\ ${ }^{1}$ kurniarangga80@gmail.com
}

\begin{abstract}
ABSTRAK
Pada era saat ini komputer sangat dibutuhkan dalam segala aspek kehidupan tidak terkecuali didunia kesehatan. Posyandu saat ini banyak memiliki peran untuk mendukung pelayanan kesehatan masyarakat. Dalam pelaksanaan posyandu tentunya banyak data yang dicatat, terutama data anak dan ibu hamil setiap data pasti ada perubahan baik itu penambahan maupun pengurangan. Hal ini bisa menyebabkan kurang efisien jika pencatatan masih manual. Tujuan peneliti ini adalah untuk merancang suatu sistem informasi pelayanan pada posyandu yang dapat mempermudah kerja para kader untuk melakukan porses pelayanan dan laporan hasil kegiatan posyandu secara efesien. Metode penelitian sistem informasi pelayanan pada Posyandu Seruni ini menggunakan metode kualitatif untuk mendapatkan informasi yang dibutuhkan. Peneliti melakukan penelitian dengan membandingkan melalui refrensi serta buku yang memuat informasi yang dibutuhkan, menganalisa kebutuhan, perancangan, implementasi, pengkodean dan pengujian. Pembuatan Sistem informasi pelayanan pada Posyandu dapat membantu kader dalam pelayanan serta laporan kegiatan dengan lebih efektif dan efisien.

Kata Kunci: Sistem, Informasi, Pelayanan, Posyandu
\end{abstract}

\begin{abstract}
In the current era, computers are needed in all aspects of life, including the word of health. Posyandu currently has many roles to support public healt services. In the implementation of posyandu, of course, a lot of data is recorded, especially data on children and pregnant women, every data there must be changes, either additions or subtractions. This can cause less efficiency if the recording is still manual. The purpose of this research is to desain a service information sistem at the posyandu that can facilitate the work of cadres to process service and report the result of posyandu activities efficiently. The research method for service information systems at the Posyandu Seruni uses qualitative methods to obtain the required information. Researchers conduct research by comparing through references and books containing the information needed, analyzing needs, designing implementation, coding and testing. The creation of a service informasi system at the posyandu can help cadres in service and report activities more effectively and efficiently.
\end{abstract}

Key Word: System, Information, Service, Posyandu,

\section{PENDAHULUAN}

Kesehatan merupakan salah satu hal penting yang harus diperhatikan oleh setiap manusia, karena kesehatan dapat dijadikan sebagai salah satu parameter yang menentukan kualitas sumber daya manusia. Kualitas kesehatan dapat dilihat dari maju tidaknya pelayanan kesehatan yang ada disuatu negara. Selain itu pemeliharaan dan perawatan dibidang kesehatan merupakan suatu strategi dalam upaya pemenuhan pelayanan kesehatan yang meliputi peningkatan kesehatan yang baik.

Peran dari posyandu yaitu sebagai kegiatan pelayanan kesehatan masyarakat pada kelompok masyarakat tingkat Rukun Warga
(RW). Karena posyandu dikelola untuk bersama masyarakat dalam penyelenggaraan pembangunan kesehatan, untuk memberikan kemudahan kepada masyarakat dalam memperoleh pelayanan kesehatan dasar untuk meningkatkan angka kesehatan anak dan ibu hamil. Serta memantau kesehatan masyarakat dan menjamin pertumbuhan dan perkembangan khususnya pada anak usia dini dengan peningkatan kesehatan masyarakat secara optimal.(Kementrian Kesehatan RI, 2011)

Perancangan sistem informasi Posyandu Seruni dibuat untuk mempermudah para kader dalam pelayanan dan laporan kegiatan lebih terstruktur karena menggunakan buku besar 
sebagai pencatatan pendataan kurang efektif, sehingga dikhawatirkan ada data yang tidak tercatat. Sistem adalah kelompok unsur yang erat hubungannya satu dengan yang lain, yang berfungsi bersama-sama untuk mencapai tujuan tertentu (Subtari, 2012). Pendataan adalah kumpulan yang terdiri dari angkaangka maupun karakter-karakter yang tidak memiliki arti(Asropudin, 2013). Perancangan sistem informasi pelayanan Posyandu Seruni ini dirancang dengan bahasa pemgrograman Java dan menggunakan database MySQL. Java adalah bahasa pemrograman komputer yang memiliki teknologi untuk membuat dan menjalankan perangkat lunak pada komputer ataupun pada lingkungan jaringan.(Shalahuddin, 2014).

Sistem yang digunakan untuk pelayanan masih manual. Jika dilihat dari segi pendaftaran, pendataan, pencarian dan laporan kegiatan. Untuk mendapatkan informasi mengenai data perkembangan yang ada, maka sebaiknya digunakan sistem informasi secara komputerisasi. Pelayanan dengan menggunakan sistem tersebut, maka Posyandu sering mengalami kesalahan dalam pembuatan laporan. Sebab dengan sistem tersebut data yang diperoleh tidak akurat, karena sistem yang sedang berjalan masih manual.

\section{METODE PENELITIAN}

Dalam mengumpulkan data dan informasi yang diperlukan, penulis berusaha melakukan beberapa peneliian secara langsung ke Posyandu Seruni di Jl. H. Terin 3 RT:05/RW:03, Kel. Pangkalanjati Baru, Kec. Cinere, Kota Depok, Jawa Barat, 16513

Metode penelitian yang digunakan oleh penulis ada Grounded Research, yaitu suatu metode penelitian yang berdasarkan pada fakta dan menggunakan analisis perbandingan dengan tujuan mengadakan generasi empiris, menetapkan konsep, membuktikan teori, mengembangkan teori, mengumpulkan data dan analisis data dalam waktu yang bersamaan. (Sugiyonto, 2011)

Metode yang digunakan dalam pengumpulan data pada penelitian ini, diantaranya:

1. Studi Kepustakaan (Library Research)

Tahap ini merupakan tahap awal pengumpulan data dari sumber-sumber seperti buku, jurnal, yang memuat informasi yang dibutuhkan. Studi pustaka dilakukan berkaitan dengan analisis dan desain sistem informasi, pelayanan posyandu, pemrogrman Java dan query MySQL.

2. Observasi

Tahap ini merupakan tahap melakukan pengamatan secara langsung terhadap pengguna sistem dan pengamatan secara langsung terhadap sistem yang sedang berjalan di Posyandu Seruni. Observasi ini dilakukan pada bagian pelayanan untuk mengetahui alur porses pelayanan.

3. Wawancara

Pada tahap ini peneliti melakukan wawancara dengan kepala posyandu dan kader sebagai pengguna sistem manual yang sedang berjalan untuk memperoleh keterangan mengenai data anak dan ibu hamil.

Adapun sistem perancangan penulis menggunakan :

1. Diagram Alir Data (DAD) adalah suatu gambaran secara grafis suatu sistem yang menggunakan beberapa simbol untuk menjelaskan bagaimana data mengalir melalui suatu mekanisme proses interaksi.

(A. Kristanto, 2010)

2. Entity Relationship Diagram (ERD) adalah suatu model jarignan yang menggunakan susunan data yang disimpan dari sistem secara baik yang mendeskripsikan hubungan antara data store dalam DFD. (H. Kristanto, 2013)

3. Kamus data adalah penjelasan tentang suatu data yang tersimpan pada database sebuah sistem. (H. Kristanto, 2011)

4. Normalisasi adalah pengelompokan atribut-atribut yang membuat entitas sederhana dengan jumlah kerangkapan datanya sedikit, serta memberikan bagi user untuk melakukan insert, delete, modify terhadap baris-baris data pada hubungan tersebut yang tidak berakibat terjadinya error data yang disebabkan oleh operasi-operasi tersebut. (Amelia, 2015)

5. Database berfungsi sebagai penampung data yang diinputkan melalui form website. (Medcom)

HASIL DAN PEMBAHASAN

Langkah-langkah dalam perancangan sistem informasi yang diusulkan:

Dekomposisi sistem yang diusulkan 


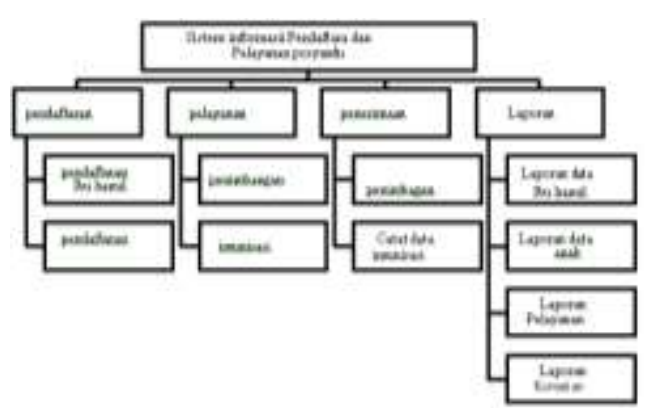

Gambar 1. Dekomposisi Fusngsi Sistem Diusulkan

Setelah membuat dekomposisi fungsi sistem maka selanjutnya membuat rancngan masukan, proses dan keluaran dengan menggunakan Diagram Alir Data.

\section{Diagram Konteks}

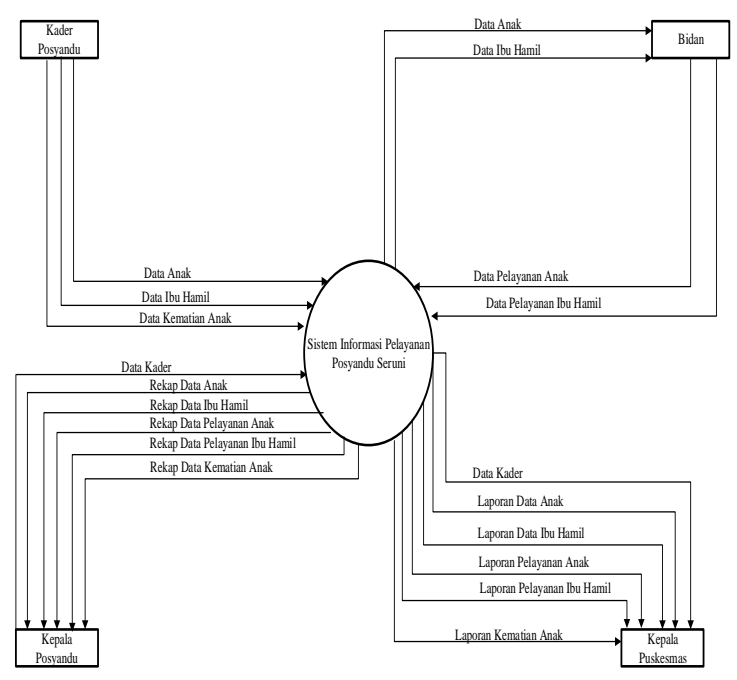

Gambar 2. Digaram Konteks Sistem yang Diusulkan

Pada diagram konteks diatas memiliki 4 terminator terdiri dari Kader Posyandu, Bidan, Kepala Posyandu, Kepala Puskesmas. Sedangkan pada proses terdapat suatu proses yaitu pendaftaran anak dan ibu hamil, pelayanan pada anak dan ibu hamil pada Posyandu Seruni. Selanjutnya dari diagram konteks atau diagram tinggat paling tinggi akan dibuat diagram dengan tingkatan sedang yaitu diagram nol.

\section{Diagram Nol}

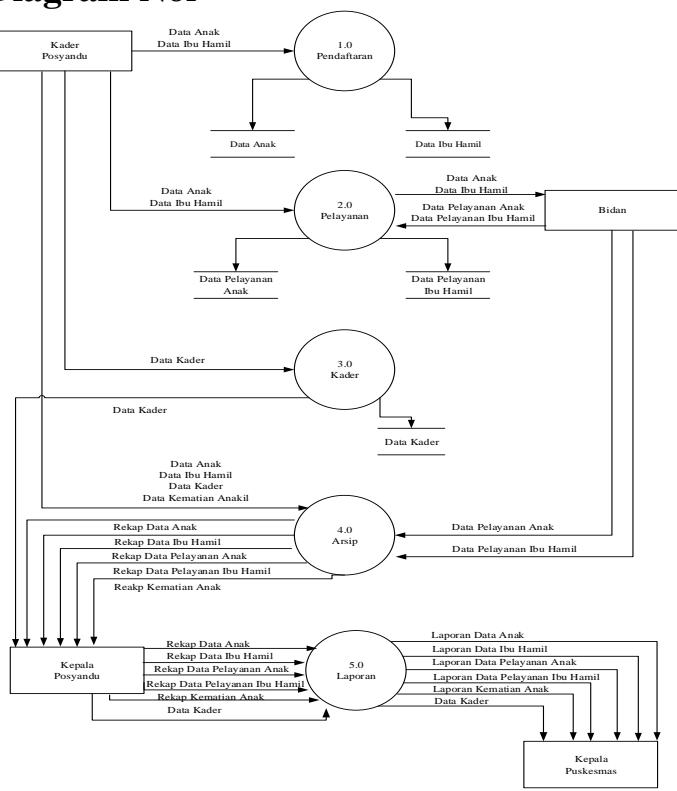

Gambar 3. Diagram Nol Sistem yang Diusulkan

Pada diagram nol diatas terdapat 4 terminator daya yang terdiri dari data kader posyandu, bidan, kepala posyandu, kepala puskesmas sedangkan terdapat 5 proses yaitu pendaftaran, pelayanan, kader, arsip, dan laporan.

Diagram Rinci Sistem Berjalan Diagram Rinci Proses 1

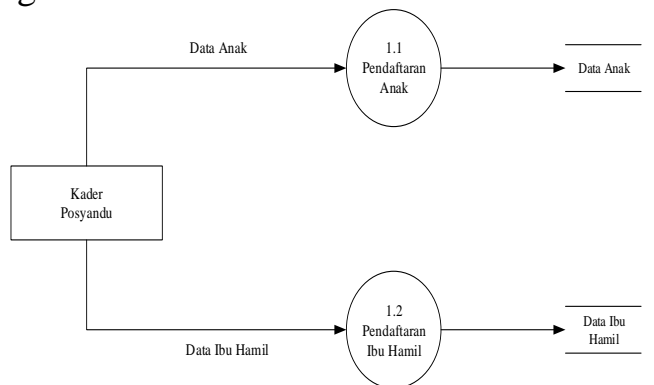

Gambar 4. Diagram Rinci 1.0 Sistem yang Diusulkam

Diagram Rinci Proses 2

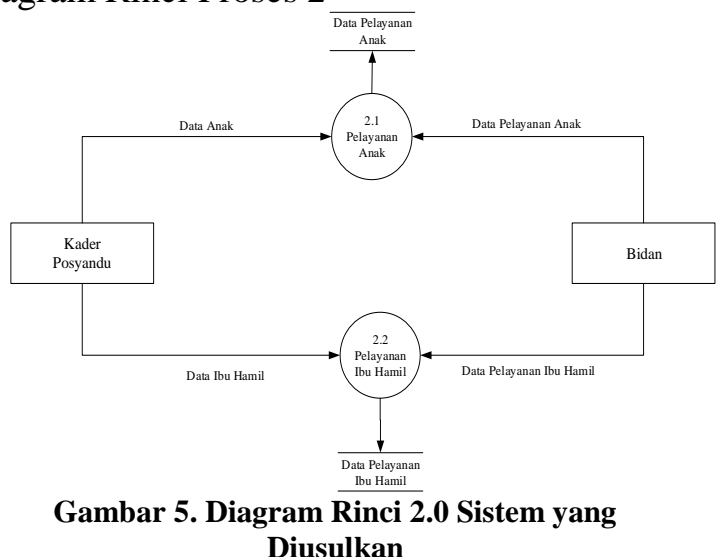




\section{Diagram Rinci Proses 4}

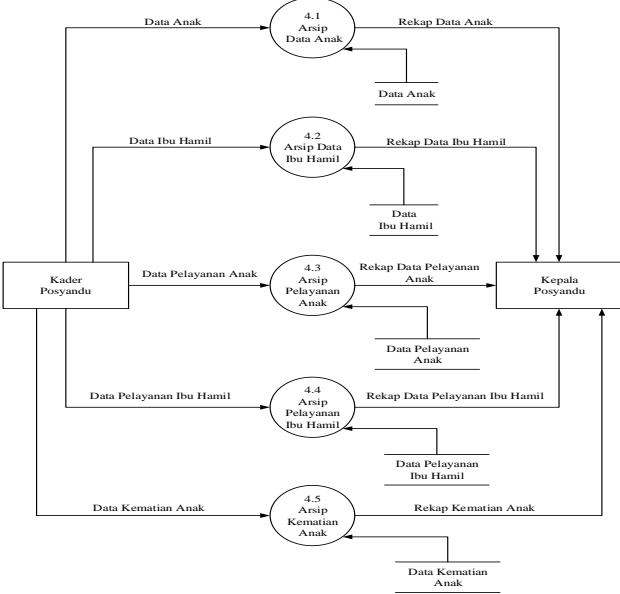

Gambar 6. Diagram Rinci 4.0 Sistem yang Diusulkan

\section{Diagram Rinci Proses 5}

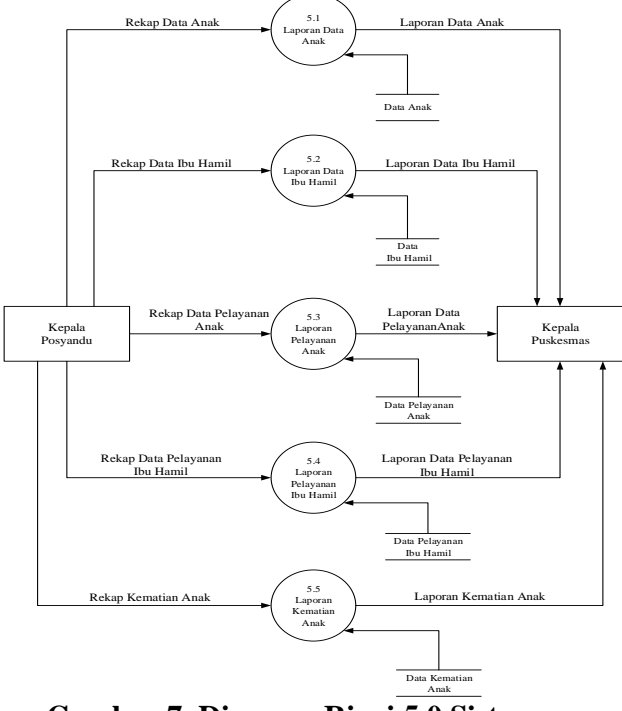

Gambar 7. Diagram Rinci 5.0 Sistem yang Diusulkan

Tampilan Login

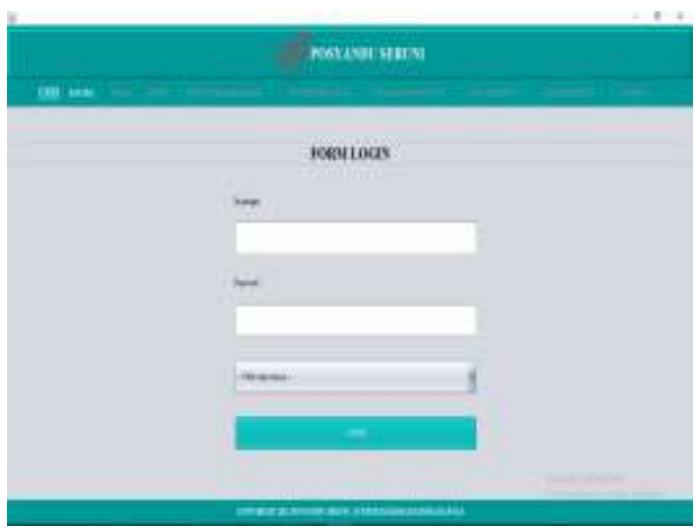

.Gambar 8. Menu Login

Masukan username dan password untuk masuk ke menu utama dengan mengklik tombol masuk.
Tampilan Menu Utama
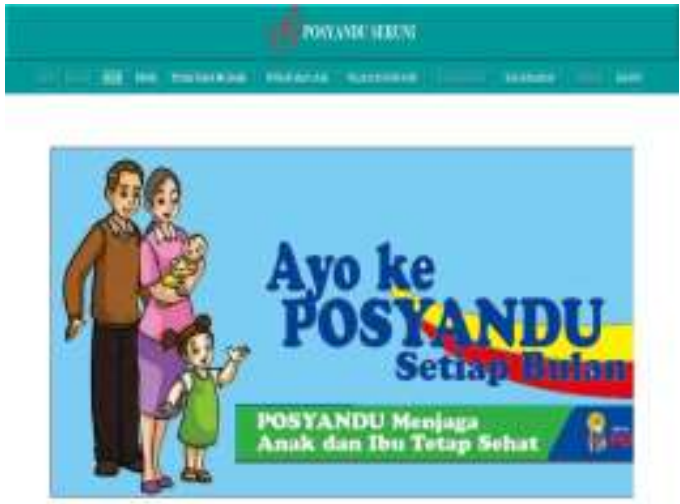

Gambar 9. Menu Utama

Setelah masuk dimenu utama pilih menu pendaftaran anak, pendaftaran ibu hamil, pemeriksaan ibu hamil, pemeriksaan anak, kematian anak, kematian ibu hamil dan laporan.

Tampilan Form Pendaftaran Anak

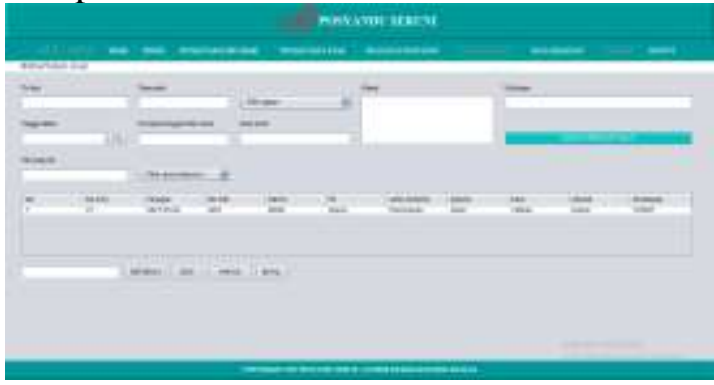

Gambar 10. Form Pendaftaran Anak

Layar ini menampilkan tampilan form pendaftaran anak, kader dapat menyimpan maupun menghapus dan mengubah data anak.

Tampilan Pendftaran Ibu Hamil

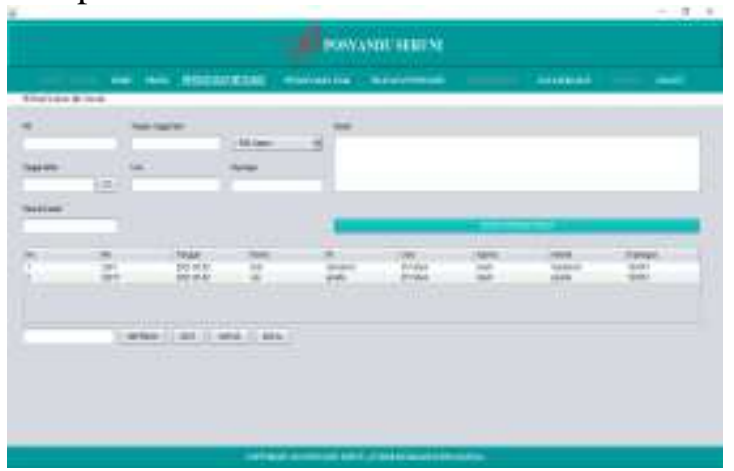

Gambar 11. Form Pendaftaran Ibu Hamil

Layar ini menampilkan tampilan form pendaftaran anak, kader dapat menyimpan maupun menghapus dan mengubah data ibu hamil. 
Tampilan Form Penimbangan

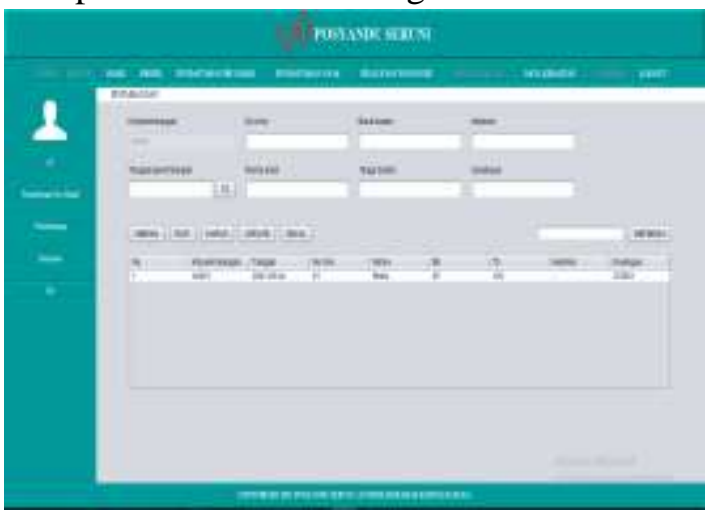

Gambar 12. Form Penimbangan

Layar ini menampilkan form penimbangan, kader dapat menyimpan dan mengubah data penimbangan.

Tampilan Form Imunisasi Anak

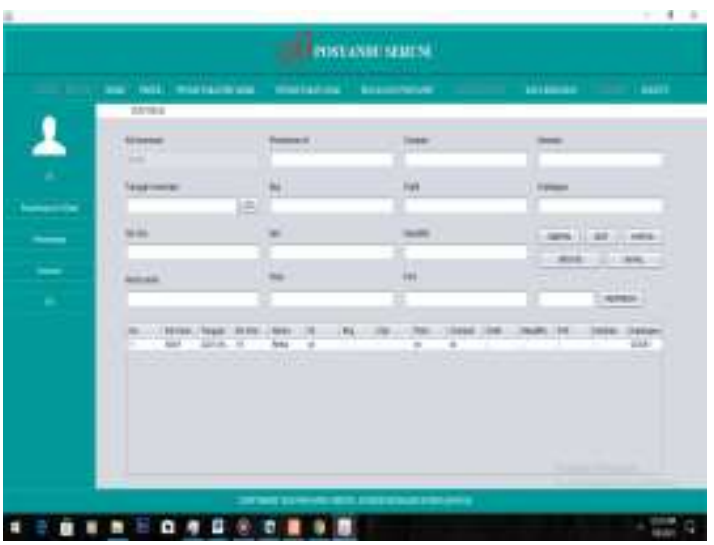

Gambar 13. Form Imunisasi Anak

Layar ini menampilkan form penimbangan, kader dapat menyimpan dan mengubah data penimbangan

Tampilan Laporan Data Anak

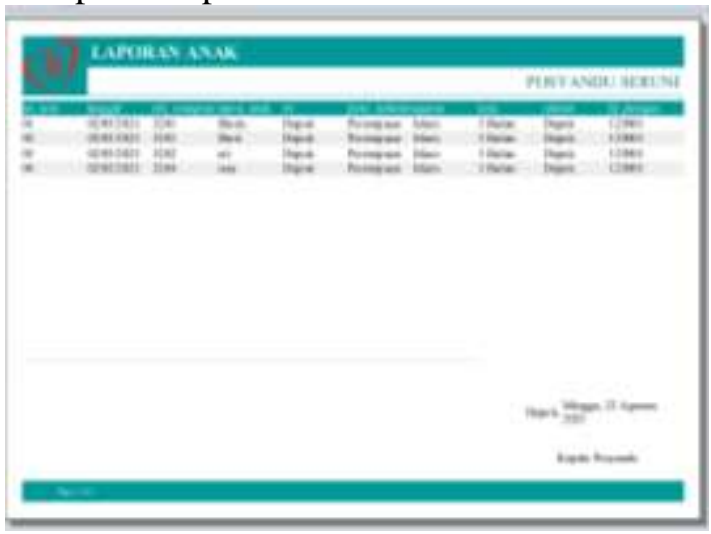

Gambar 14. Laporan Data Anak

Layar ini menampilkan laporan data anak yang sudah terinput.
Tampilan Laporan Data Ibu Hamil

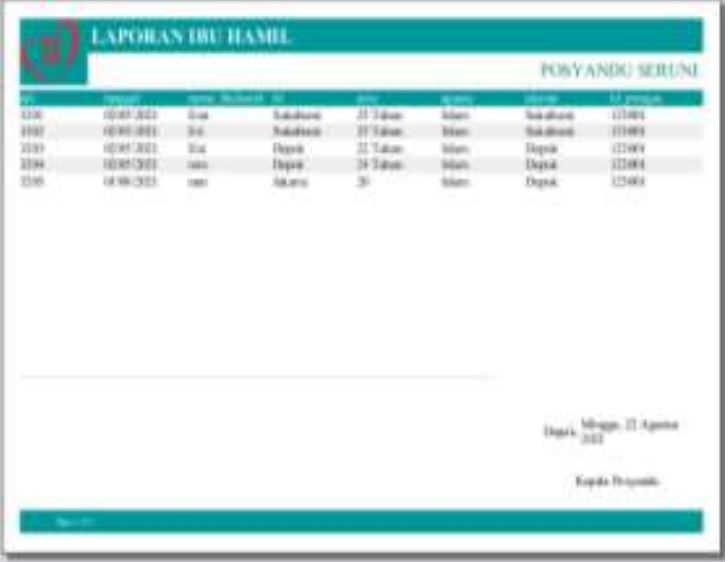

Gambar 15. Laporan Data Ibu Hamil

Layar ini menampilkan laporan data ibu hamil yang sudah terinput.

Tampilan Laporan Penimbangan

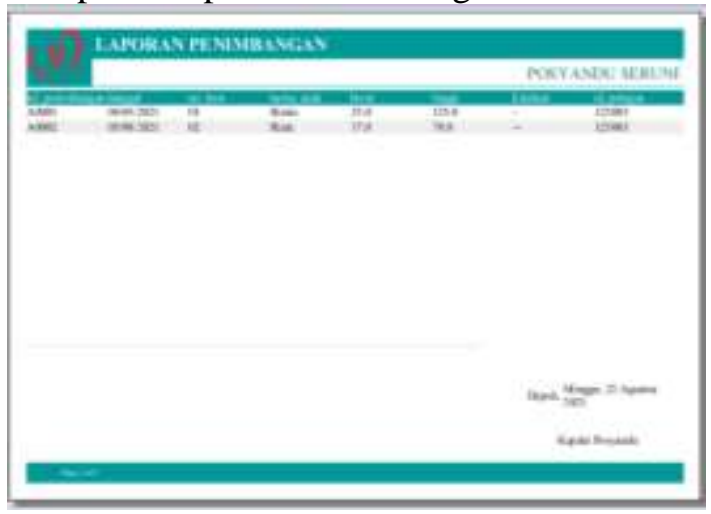

Gambar 16. Laporan Penimbangan

Layar ini menampilkan laporan penimbangan yang sudah terinput

Tampilan Laporan Imunisasi

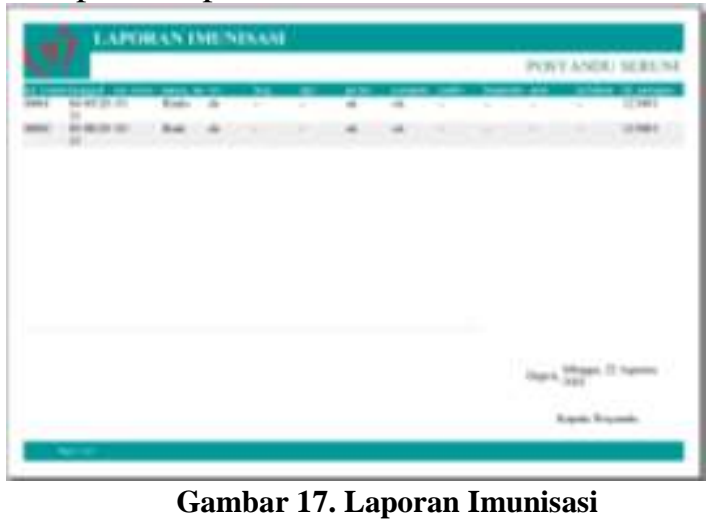

Layar ini menampilkan laporan data anak yang sudah terinput.

\section{SIMPULAN DAN SARAN}

Dengan dibuatnya aplikasi sistem informasi pelayanan pada Posyandu Seruni semua 
kegiatan yang berhubungan dengan pengolahan data sistem informasi dapat berjalan dengan baik dan lancer. Pada aplikasi ini, bagian kader dapat menginput data anak dan data ibu hamil dengan cepat dan akurat, serta bidan dapat melakukan pelayanan untuk anak dan ibu hamil berupa penimbangan dan imunisasi anak dengan cepat dan akurat.

Hasil Perancangan aplikasi sistem informasi ini juga membutuhkan partisipasi aktif dari pemakai sistem, data yang di input harus sesuai, agar tidak ada kesalahan saat pendataan pada anak dan ibu hamil di Posyandu Seruni tepat sasaran. Adapun keuntungan program aplikasi pelayanan adalah : dengan adanya Sistem Informasi Pelayanan Posyandu ini dapat memudahkan para kader posyandu dalam melakukan pelayanan pada Posyandu Seruni. Dengan menggunakan sistem informasi pelayanan Posyandu ini menjadi lebih efisien waktu sera mempermudah kinerja para kader posyandu dalam pembuatan laporan posyandu, dengan sistem ini data-data yang disimpan didalam database lebih aman dan terstruktur serta pembuatan laporan lebih mudah
DAFTAR PUSTAKA

Amelia, M. (2015). Sistem Pengolahan Data Barang Paisley Thing. Jakarta: Universitas Indraprasta PGRI.

Andi dan Medcom. (2011). Aplikasi Programing \& Database Manajement for Beginners.

Asropudin. (2013). Kamus Teknologi Informasi Komunikasi. Bandung: Titian Ilmu.

Kementrian Kesehatan RI, S. J. (2011). Pedoman Umum Pengelolaan Posyandu. Jakarta Kementrian Kesehatan RI.

Kristanto, A. (2010). Perancangan Sistem Informasi dan Aplikasinya. Yogyakarta: Andi Ofset.

Kristanto, H. (2011). Konsep Dasar Perancangan Sistem. Yogyakarta: Graha Ilmu.

Kristanto, H. (2013). Konsep dan Perancangan Database. Yogyakarta: andi.

Shalahuddin, M. \& A. S. (2014). Rekayasa Perangkat Lunak Terstruktur dan Berorientasi Objek. Bandung: Jurnal Pilar Nusa Mandiri.

Subtari. (2012). Analisa sistem informasi. Yogyakarta: andi.

Sugiyonto. (2011). Metode Penelitian Bisnis. Kuantitatif, Kualitatif dan $R \& D$. Bandung: Alfabeta. 